\title{
The pathogenicity and importance of seed-borne infection by Bipolaris sorokiniana on barley in Finland
}

\author{
AARNE KURPPA \\ Department of Plant Pathology, University of Helsinki* \\ SF-00710 HELSINKI 71 Finland
}

\begin{abstract}
Seed-borne infection by Bipolaris sorokiniana decreased the percentage germination of barley seeds and the emergence of seedlings. Infection levels were higher in nongerminated than in germinated seeds. Seed treatment with organomercurial fungicide or imazalil improved the percentage emergence but a low number of diseased seedlings still remained in the crops. The fungus caused a reduction in grain yields in most experiments and also decreased their value as sowing seed, if the weather conditions were favourable for complite disease expression. Yield losses in greenhouse experiments varied from 7.2 to $38.5 \%$ and in the field from 5 to $11 \%$, and showed a strong correlation with the infection levels in the seed stocks. Higher losses were associated with the six-row cultivars. Organomercury seed treatment resulted in a slight but insignificant increase in yields but it was able to prevent an occurrence of secondary infection in the crop resulting in a lower seed infection levels of the grain. In field experiments in Inari $\left(69^{\circ}\right.$ N.L.) seed-borne inoculum could be demonstrated clearly to be the only source of a severe disease outbreak. The inoculum remaining in the soil was capable of initiating soil-borne infection of barley seedlings during the following two growing seasons.
\end{abstract}

\section{Introduction}

Bipolaris sorokiniana (Sacc. ex Sorok.) Shoem. (syn. Helminthosporium sativum Pamm., King \& Bakke), perfect state Cochliobolus sativus (Ito \& Kurib.) Dastur has been recently reported to be increasingly common in commercial barley seed stocks in

\footnotetext{
* Present address: Agricultural Research Centre Department of Plant Pathology

SF-31600 JOKIOINEN, Finland
}

North Western Europe (de TemPE 1964, JøRGENSEN 1974, Hewett 1975, Olofsson 1976, KurPPA 1984). Estimates concerning its economic importance have been variable but the latest information assumes losses in yield of up to $15 \%$ due to a high level of seed infection (Whittle \& Richardson 1978). Diseased plants from infected seeds have also been found serving as important sources for spore liberation during later developmental stages of the crop, and their residues remain

Index words: Bipolaris sorokiniana, Helminthosporium sativum, Cochliobolus sativus, common root rot, kernel blight 
objects for further sporulation (CHINN 1977, ReIs \& WünSCHE 1984).

The persistence of $\boldsymbol{B}$. sorokiniana in barley seed for 10 years or more precludes ageing as practical method for obtaining seeds free from the pathogen (MACHACEK \& Wallace 1952, Couture \& Sutton 1980). Seed treatment with organomercurial or systemic fungicides (Hewett 1975, Chinn 1978, Whittle \& RICHARDSON 1978) has resulted in satisfactory control of the disease.

\section{Materials and Methods}

Determination of percentage germination in seed stocks including examination for fungal growth was carried out in petri dishes as described by KurPPA (1984). Percentage emergence was determined by the official method used at State Seed Testing Institute, Helsinki. Field experiments at Viikki, Helsinki and Muddusniemi Research Station, Inari, and pot experiments at Viikki were designed to study disease development, varietal differences and the effects of seed-borne disease and seed treatment on grain yield and infection levels. Seed stocks used for sowing in the experiments originated from a field experiment at Viikki (KurPPA 1985 b.), or were selected from commercial stocks examined at State Seed Testing Institute. This material included stocks with various levels (19-92\%) of seed and embryo infection, and was classified according to the latter parameter. Class a indicates low, b moderate and $\mathrm{c}$ high infection levels.

In greenhouse experiments barley was grown in plastic $25 \times 25 \mathrm{~cm}$ pots filled with non-sterilized loamy field soil, which was previously determined to be free of the pathogen. In field experiments a plot size of $5 \times$ $1.33 \mathrm{~m}$ was used. Experimental soils were fertilized with a commercial N-P-K (15-20-15) fertilizer, $500 \mathrm{~kg} / \mathrm{ha}$ in field experiments or $3 \mathrm{~g} /$ pot in greenhouse experiments. For seed treatment an organomercuric fungicide (Ceresan $2 \mathrm{~g} / \mathrm{kg}$ seeds), benomyl (Benlate $1 \mathrm{~g} / \mathrm{kg}$ and imazalil (experimental sample $0.3 \mathrm{~g}$ a.i. $/ \mathrm{kg}$ ) were used. In the field barley was sown in a density of 400 (six-row cvs) or 450 (two-row cvs) seedlings $/ \mathrm{m}^{2}$ and in greenhouse experiments 50 seeds were sown/pot. The pots were watered as required with an equal volume per pot of tap water.

The seedling population was counted at the 3-4 leaf stage and samples (25 seedlings/plot) were collected in the field. The second sampling occurred close to the yellow ripening stage. Basal stems of the plants showing disease symptoms were surface-sterilized with Na-hypochloride and plated on potato dextrose agar (PDA). After 7 days of incubation at room temperature the samples were examined for the presence of $B$. sorokiniana. Pots and field plots were harvested when ripe, grain yields were drained immediately, weighed, and samples were taken for grain analysis.

Analysis of variance and linear regression equations with correlation coefficients was used to test the signicance of the results.

The weather conditions at Viikki during research period were as follows: The growing seasons of 1973 and 1975 were warm and dry, the season of 1979 was near average and the rest were cooler than average with high rainfall (ANON 1973-1979).

\section{Results}

B. sorokiniana significantly decreased percentage germination in all stocks of seed infected at various levels (Table 1). Nongerminated seeds carried higher levels of infection in all seed classes of all barley cultivars tested. Reduction in percentage germination was particularly related to embryo infection by the fungus (Fig. 1). The fungus had a stronger effect on field emergence than on laboratory germination of the seeds ( $\mathrm{Ta}$ ble 2). A high number of young infected seedlings failed to emerge and those capable doing so showed seedling blight symptoms (Fig. 5). The mean percentages of reduction in emergence of seedlings in 14 pot experiments and 18 field experiments were record- 

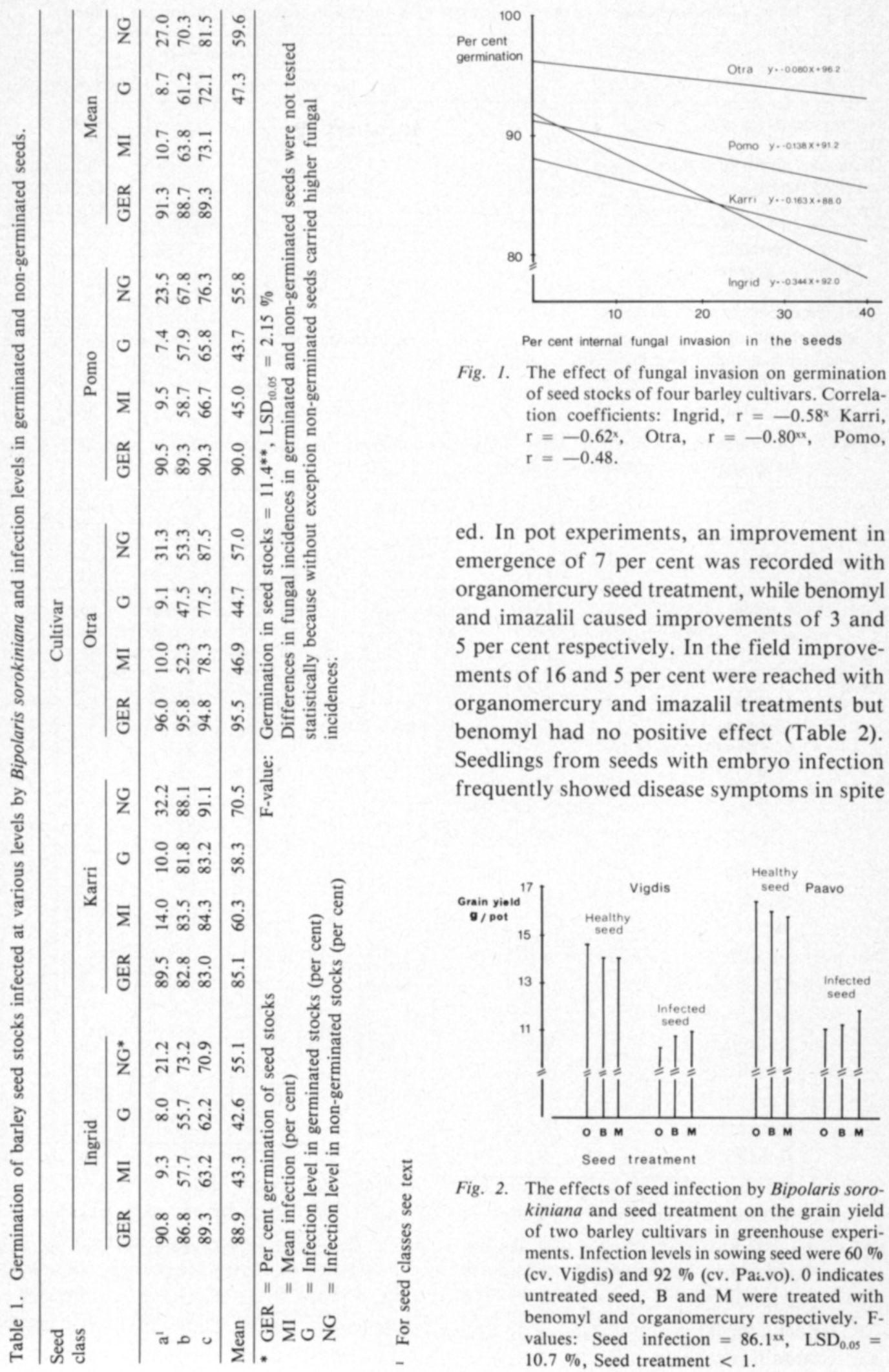

Fig. 1. The effect of fungal invasion on germination of seed stocks of four barley cultivars. Correlation coefficients: Ingrid, $\mathrm{r}=-0.58^{\times}$Karri, $r=-0.62^{x}$, Otra, $r=-0.80^{x x}, \quad$ Pomo, $r=-0.48$.

ed. In pot experiments, an improvement in emergence of 7 per cent was recorded with organomercury seed treatment, while benomyl and imazalil caused improvements of 3 and 5 per cent respectively. In the field improvements of 16 and 5 per cent were reached with organomercury and imazalil treatments but benomyl had no positive effect (Table 2). Seedlings from seeds with embryo infection frequently showed disease symptoms in spite

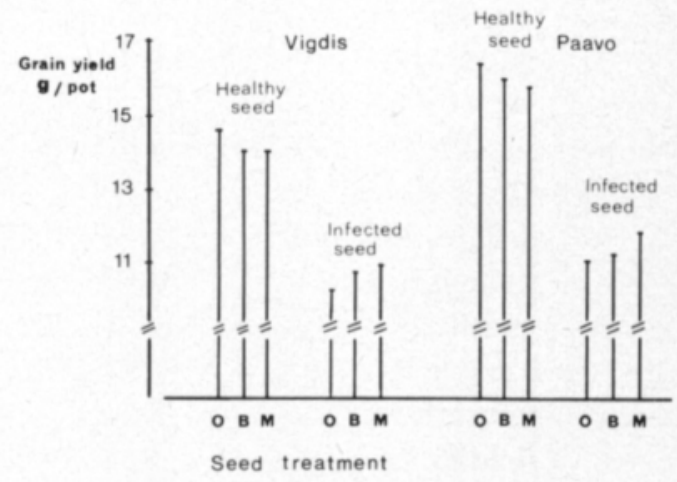

Fig. 2. The effects of seed infection by Bipolaris sorokiniana and seed treatment on the grain yield of two barley cultivars in greenhouse experiments. Infection levels in sowing seed were $60 \%$ (cv. Vigdis) and $92 \%$ (cv. Pai.vo). 0 indicates untreated seed, B and $\mathrm{M}$ were treated with benomyl and organomercury respectively. Fvalues: Seed infection $=86.1^{\mathrm{xx}}, \mathrm{LSD}_{0.05}=$ $10.7 \%$, Seed treatment $<1$. 
Table 2. Emergence of barley seed infected with Bipolaris sorokiniana, with and without seed treatment.

\begin{tabular}{|c|c|c|}
\hline Treatment & Emer & \\
\hline & Greenhouse experiments & Field experiments \\
\hline Healthy untreated seed & $94.5^{*}(7)^{1}$ & $55.3^{2} \quad(4)$ \\
\hline Untreated infected seed $^{3}$ & $80.5 \quad$ (7) & $45.1 \quad$ (4) \\
\hline Organomercury treated infected seed & $86.4 \quad(7)$ & $52.2 \quad(4)$ \\
\hline Benomyl treated & $82.7 \quad$ (4) & $44.9 \quad(2)$ \\
\hline Imazalil treated & $84.7 \quad$ (2) & $47.3 \quad(2)$ \\
\hline
\end{tabular}

* Per cent emergence

I Number of experiments

2 Number of seedlings/drill $\mathrm{m}$

3 Infection levels from 19 to $92 \%$

In all individual experiments analyzed statistically, organomercury seed treatment of infected seed significantly increased germination and emergence at $\mathrm{P}=0.05$ level.

Table 3. The effects of seed infection levels of Bipolaris sorokiniana and of seed treatment on grain yields of four barley cultivars in greenhouse experiments.

\begin{tabular}{|c|c|c|c|c|c|c|c|c|c|c|c|}
\hline \multirow{3}{*}{$\begin{array}{l}\text { Seed } \\
\text { class }\end{array}$} & \multicolumn{11}{|c|}{ Cultivar } \\
\hline & \multicolumn{2}{|c|}{ Ingrid } & \multicolumn{2}{|c|}{ Karri } & \multicolumn{2}{|c|}{ Otra } & \multicolumn{2}{|c|}{ Pomo } & \multicolumn{3}{|c|}{ Means } \\
\hline & $0^{1}$ & 1 & 0 & 1 & 0 & 1 & 0 & 1 & 0 & 1 & $0+1$ \\
\hline$h^{2}$ & $100.0^{*}$ & 103.7 & 100.0 & 104.0 & 100.0 & 89.5 & 100.0 & 98.5 & 100.0 & 99.0 & 99.5 \\
\hline b & 102.2 & 94.7 & 84.2 & 83.7 & 90.5 & 96.5 & 79.2 & 78.7 & 89.0 & 88.4 & 88.7 \\
\hline c & 94.5 & 91.2 & 93.2 & 90.5 & 85.7 & 76.7 & 78.0 & 66.7 & 87.8 & 81.3 & 84.6 \\
\hline Mean & 98.9 & 96.6 & 92.5 & 92.8 & 92.1 & 87.6 & 85.7 & 81.3 & 92.2 & 89.6 & \\
\hline
\end{tabular}

$10=$ Untreated seed

1 = Organomercury treated seed

$2 \mathrm{~h}=$ Healthy seed

b $=$ Embryo infection levels from 4 to $10 \%$

$c=\quad-n-\quad 22$ to $36 \%$

* Relative grain yield; controls for each cultivar $=100.0$
F-values: Infection levels $=71.3^{\mathrm{x}}, \mathrm{LSD}_{\mathrm{t} 0.05}=2.8 \%$

Cultivars $=10.8^{\mathrm{xx}}, \quad=9.0 \%$

Seed treatment $<1$

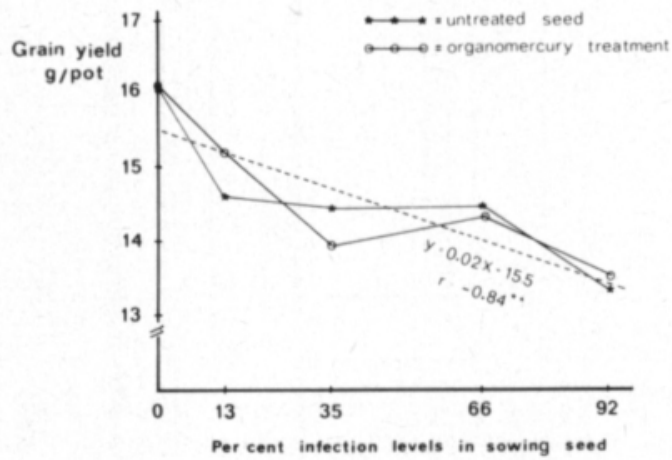

Fig. 3. The effects of seed infection level and seed treatment with organomercury powder on grain yields of barley cultivar Paavo in greenhouse experiments. F-values: Seed infection level $=50.9 \mathrm{x}, \mathrm{LSD}_{0.05}=0.44 \mathrm{~g}$, Seed treatment $<1$.

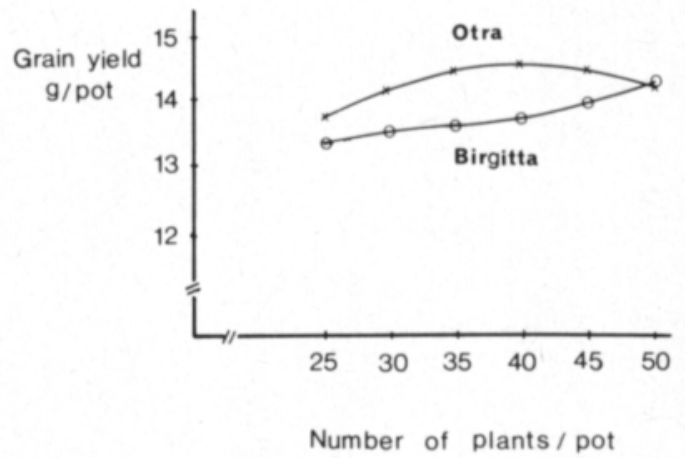

Fig. 4. The effect of plant density on grain yields of barley cvs. Birgitta and Otra. For sowing, pathogen-free seed was used. F-value $=1.8$, not significant. 
Table 4. The effects of seed infection and seed treatment on yield and infection incidence in grain on barley cv. Vigdis in a field experiment.

\begin{tabular}{|c|c|c|c|c|c|c|}
\hline \multirow[t]{2}{*}{ Seed treatment } & \multicolumn{3}{|c|}{$\begin{array}{l}\text { Grain yield } \mathrm{kg} / \mathrm{plot} \\
\text { Sowing seed }\end{array}$} & \multicolumn{3}{|c|}{$\begin{array}{l}\% \text { incidence of } B \text {. sorokiniana } \\
\text { Sowing seed }\end{array}$} \\
\hline & Healthy & Infected* & Mean & Healthy & Infected & Mean \\
\hline None & 3.415 & 3.090 & 3.252 & 3.3 & 17.5 & 10.4 \\
\hline Benomyl & 3.225 & 3.082 & 3.153 & 8.3 & 22.5 & 15.4 \\
\hline Organomercury & 3.300 & 3.507 & 3.403 & 4.0 & 7.5 & 5.7 \\
\hline Mean & 3.313 & 3.226 & & 5.2 & 15.8 & \\
\hline
\end{tabular}

* Seed infection level $=60.0 \%$

$\begin{array}{rlrl}\text { F-values: Sowing seed/yield } & =4.7^{\mathrm{x}}, \mathrm{LSD}_{10.05} & =0.316 \mathrm{~kg} \\ -n-\text { /infection incidence in grain } & =34.2^{\mathrm{xx},} & & =5.8 \% \\ \text { Seed treatment/ } \quad-n- & =7.4^{\mathrm{x}}, & & =7.7 \%\end{array}$

Table 5. Pathogenicity of seed-borne infection of Bipolaris sorokiniana on five barley cultivars in field experiments and the effect of seed treatment to control the disease.

\begin{tabular}{|c|c|c|c|c|c|c|c|c|c|c|c|c|c|}
\hline \multirow{3}{*}{$\begin{array}{l}\text { Seed } \\
\text { treatment }\end{array}$} & \multicolumn{13}{|c|}{ Cultivar } \\
\hline & \multicolumn{2}{|c|}{ Otra } & \multicolumn{2}{|c|}{ Vigdis } & \multicolumn{2}{|c|}{ Karri } & \multicolumn{2}{|c|}{ Pomo } & \multicolumn{2}{|c|}{ Ingrid } & \multicolumn{3}{|c|}{ Mean } \\
\hline & $\mathbf{H}^{\prime}$ & I & H & I & $\mathrm{H}$ & I & $\mathrm{H}$ & I & H & I & H & I & $\mathrm{H}+\mathrm{I}$ \\
\hline \multirow{2}{*}{$\begin{array}{l}\text { None } \\
\text { Organo- } \\
\text { mercury }\end{array}$} & $100.0^{*}$ & 93.5 & 100.0 & 89.0 & 100.0 & 95.0 & 100.0 & 95.0 & 100.0 & 96.5 & 100.0 & 93.7 & 96.9 \\
\hline & 96.2 & 93.2 & 98.4 & 93.4 & 102.5 & 97.9 & 101.8 & 95.1 & 101.5 & 96.9 & 100.0 & 95.4 & 97.7 \\
\hline Mean & 98.1 & 93.4 & 99.2 & 91.2 & 101.3 & 96.5 & 100.9 & 95.0 & 100.7 & 96.7 & 100.0 & 94.5 & \\
\hline Imazalil & 94.9 & 92.3 & 95.9 & 90.6 & 95.1 & 94.0 & & & & & & & \\
\hline Mean & 97.0 & 93.0 & 98.1 & 91.0 & 99.2 & 95.6 & & & & & & & \\
\hline \multicolumn{14}{|c|}{$\begin{array}{l}\mathrm{H}=\text { Healthy seed; } \mathrm{I}=\text { Seed infected at levels from } 60 \text { to } 84 \% \\
\text { * Relative mean grain yield of three experiments; controls for each }\end{array}$} \\
\hline F-values: & $\begin{array}{l}\text { eed infect } \\
\text { rganome } \\
\text { rganome }\end{array}$ & $\begin{array}{l}\text { tion/gr } \\
\text { rcury s } \\
\text { rcury }\end{array}$ & $\begin{array}{l}\text { in yield } \\
\text { ed treat } \\
\text { Imazal }\end{array}$ & $\begin{array}{l}\text { (all cu } \\
\text { ment o } \\
\text { il treat }\end{array}$ & $\begin{array}{l}\text { tivars) } \\
\text { infecte } \\
\text { nent (cv }\end{array}$ & seed & $\begin{array}{l}\text { Il cultiv } \\
\text { Otra an }\end{array}$ & $\begin{array}{l}\text { ars) } \\
\text { d Vigdis) }\end{array}$ & $\begin{array}{l}=3 \\
= \\
<\end{array}$ & $\begin{array}{l}1.4^{x x}, 1 \\
1.3\end{array}$ & $\mathrm{SD}_{\mathrm{t0.05}}$ & $4.9 \%$ & \\
\hline
\end{tabular}

of previous seed treatment and their further development typically resulted in root rot with low grain yield (Fig. 6).

The diseases on barley originating from seed-borne infection by $B$. sorokiniana resulted in significant losses in grain yield in most experiments and also in a decrease in its value as sowing seed, if the weather conditions were favourable for complete disease expression. A mean yield reduction of $38.5 \%$ was reached in one series of pot experiments (Fig. 2) but in another (Table 3) it was lower with the following means for the cultivars: Ingrid 7.2, Karri 8.1, Otra 18.8 and Pomo $27.6 \%$.
Table 6. The effects of seed infection and seed treatment on estimated grain yield and its infection incidence in barley cv. Vigdis in a field experiment in Inari (69 $9^{\circ}$ N.L.).

\begin{tabular}{lcrr}
\hline Seed & $\begin{array}{c}\text { Grain } \\
\text { yield }\end{array}$ & \multicolumn{2}{c}{$\begin{array}{c}\text { Incidence of } \\
\text { B. sorokiniana } \\
\text { in grains }\end{array}$} \\
\cline { 3 - 4 } & & II $^{1}$ & EI \\
\hline Healthy untreated & $227.8^{*}$ & 25.5 & 4.5 \\
Infected - -2 & 224.2 & 32.7 & 10.5 \\
$-"-$ benomyl treated & 223.6 & 36.0 & 11.5 \\
- " - organomercury & & & \\
treated & 223.0 & 32.3 & 9.5 \\
\hline
\end{tabular}

I II = Infection incidence in the grains (\%)

$\mathrm{EI}=$ Embryo infection $\quad-n-$

* Grain yield $\mathrm{g} / 200$ heads

2 Infection level in the seed $=60 \%$ 


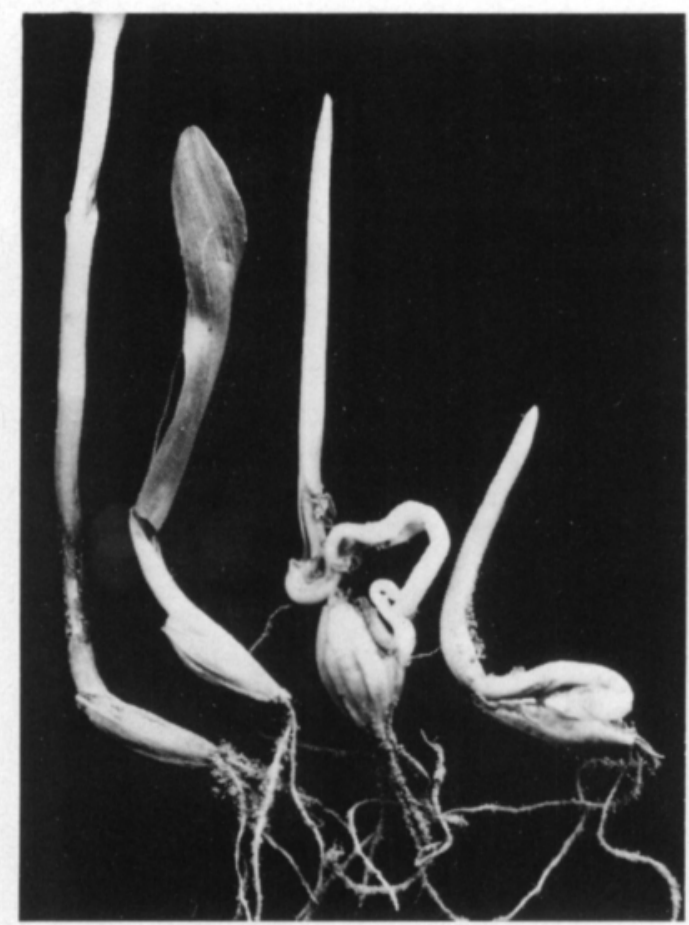

Fig. 5. Seedling blight and pre-emergence blight originating from seed-borne infection in field experiments.

An experiment with seed stocks of $\mathrm{cv}$. Paavo containing various infection levels presented a significant correlation between infection level and grain yield (Fig. 3). Organomercury or benomyl seed treatment had a minor effect on yield improvement in pot experiments (Table 3, Figs 2 and 3), although a delay in disease expression was observed. A variation in population from 25 to 50 seedlings per pot in the healthy crop had no significant effect on yield (Fig. 4).

Seed-borne infection by the fungus resulted in a relatively low but in most cases significant reduction in yields in field experiments. A $60 \%$ level of seed infection caused a mean reduction in yield of $9 \%$ on barley cv. Vigdis without seed treatment (Table 4). Organomercury seed treatment, however, significantly improved the yield but benomyl failed to do so. Infection levels in grain yields from the plots sown with infected untreated or benomyl treated seed were significantly higher than from the rest of the plots.

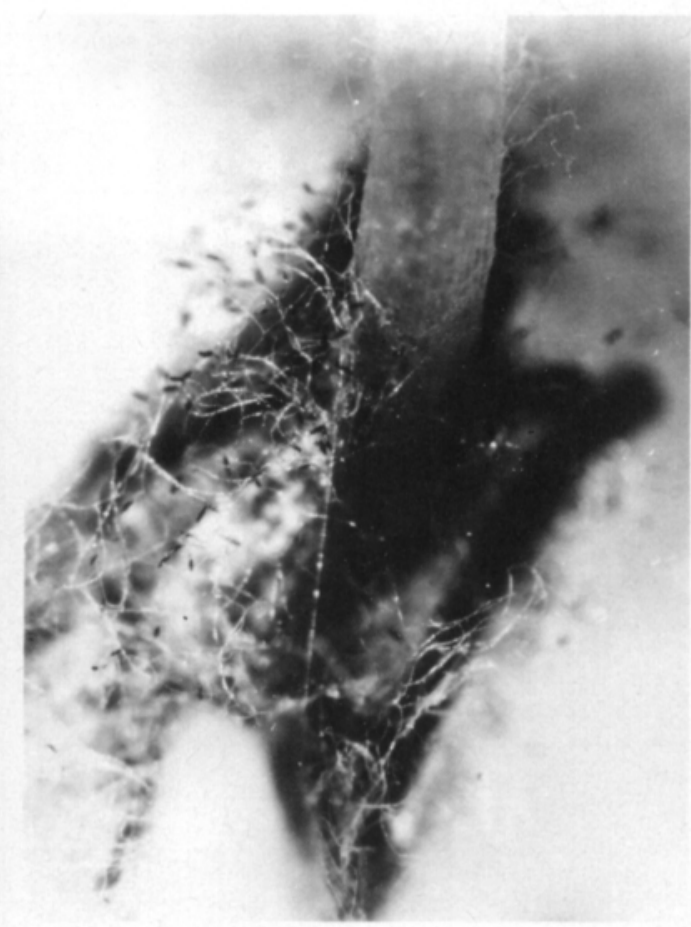

Fig. 6. Fungal growth originating from infected organomercury treated seed.

Field experiments with five barley cultivars over three years resulted in a mean reduction of $6.3 \%$ (ranging from 5-11\%) in the yields from the plots sown with moderately or highly infected seed without seed treatment (Table 5). Organomercury seed treatment increased the yield somewhat but the treatment remained insignificant. Secondary infection frequency in the crops during the experimental years $(1975-1977)$ remained low and no outstanding foliar disease or grain infection occurred.

The effect of seed-borne infection on the foliar disease outbreak could be clearly demonstrated with field experiments in Inari, Lapland, where the fungus was naturally absent. The fungus, which initiated from primarily diseased seedlings, sporulated intensively and caused an epidemic in the experimental crops, resulting also in high incidences in infection in the grain (Table 6). A high level of fungal inoculum remained in the soils with the crop residues and was ca- 
pable of infecting barley seedlings in the following two growing seasons.

\section{Discussion}

The seed-borne inoculum of Bipolaris sorokiniana is unquestionably of great importance in initiating root rot and foliar diseases on barley grown in cool and temperate regions with relatively high rain fall during growing seasons. This significance is supported by the lifecycle of the fungus as well as by the high incidences of seed infection on barley reported by de TEMPE (1964), JøRGEN. SEN (1974), Whittle (1977) and KurpPa (1984).

There is a lack of agreement on the effect of the fungus on seed germination. Reports published by de Tempe (1964) and HewetT (1975) deny its importance but a number of studies including the present support it. A study by CLARK and WALLEN (1969) reports a reduction in germination of as high as $38 \%$. Comparable data on the reduction in emergence has been reported by OLOFSSON (1976). In the present study, yield losses in field experiments due to the fungus were similar to those reported by WHITtLE and RicHARDSON (1978), but the increase in the yield as a result of seed treatment remained lower. A high incidence of fungus located deebly embedded in the grain embryos probably decreased the effectiveness of control obtained with seed treatment. Due to this factor a sufficient number of diseased plants existed in the crop able to initiate secondary infection of the fungus when weather conditions were favourable.

Among the fungicides used for seed treatment the organomercurial compound was fairly effective eradicating the fungus from superficially infected seeds but was not capable of controlling disease initiating from internally infected seeds. Severe outbreaks of the disease in barley originating from organomercury treated seed as reported by Whittle (1977) could probably be explained by this phenomen. The yields from the plots sown with imazalil treated seeds remained lower than those from organomercury treated seeds although this fungicide was highly effective on the fungus as also reported by Chinn (1978). Possibly the dose of $0.3 \mathrm{~g}$ a.i. $/ \mathrm{kg}$ seeds was too high, causing toxic effects on young barley seedlings. A number of systemic fungicides effective against $\boldsymbol{B}$. sorokiniana have been shown to be phytotoxic to barley by Couture and Sutton (1978). The ineffectiveness of benomyl treatment against the fungus agrees with the observations of RICHARDSON (1972).

The differences in yield losses between cultivars remained less significant than expected, regarding the earlier information by KURPPA (1985 a., b.) on varietal susceptibility to soilborne and secondary infection. The differences were, however, comparable to those in the previous studies. The lack of outstanding varietal differences is probably due to the high levels of infection in the seed stocks of all cultivars tested. However, a few specific cultivars have always been associated with a high seed infection level.

Seed-borne infection of $B$. sorokiniana in barley was clearly demonstrated to be an important or even the only way for the fungus to initiate the disease in remote areas. The present study reports for the first time the ability of $B$. sorokiniana to overwinter in soil and then to induce disease in barley north of the Artic Circle.

Acknowledgements. The State Seed Testing Institute is acknowledged for providing research material. I also wish to thank Ms. Jennifer Shier for linguistic revision of the English text. 


\section{References}

Anon. 1973-1979. Kuukausikatsauksia Suomen sảäoloihin. Ilmatieteen laitos, Helsinki.

ChinN, S.H.F. 1977. Influence of fungicide sprays on sporulation of Cochliobolus sativus on Cypres wheat and on conidial populations in soil. Phytopath. 67: $133-138$.

,- 1978 . Influence of seed treatment with imazalil on common root rot and the size of the subcrown internode of wheat. Phytopath. 68: 1662-1666.

Clark, R.V. \& Wallen, V.R. 1969. Seed infection of barley by Cochliobolus sativus and its influence on yield. Can. PI. Dis. Surv. 49: 60-64.

Couture, L. \& Sutton, J.C. 1978. Efficaties of fungicides in cotrolling spot blotch of barley. Can. J. Pl. Sci. 58: $311-317$.

,- 1980 . Effect of dry heat treatments on survival of seed borne Bipolaris sorokiniana and germination of barley seed. Can. PI. Dis. Surv. 60: 59-61.

Hewett, P.D. 1975. A health survey of seed barley. Pl. Path. 24: 229-232.

Jørgensen, J. 1974. Occurence and importance of seed borne inoculum of Cochliobolus sativus on barley in Denmark. Acta Agric. Scand. 24: 49-54.

KurPPA, A. 1984. Bipolaris sorokiniana on barley seed in Finland. J. Agric. Sci. Finl. 56: 175-181.

-, 1985 a. Reaction of spring barley cultivars grown in Finland to soil-borne infection by Bipolaris sorokinia$n a$ and to its toxic metabolites. J. Agric. Sci Finl. 57: 85-96.
,$- 1985 \mathrm{~b}$. The response of some spring barley cultivars grown in Finland to air-borne secondary infection by Bipolaris sorokiniana. J. Agric. Sci. Finl. 57: 97-105.

MachaceK, J.F. \& Wallace, H.A.H. 1952. Longevity of some common fungi in cereal seed. Can. J. Bot. 30: $164-169$.

OLOFSSON, B. 1976. Undersökningar rörande Drechslera-arter hos korn och havre. Meddn St. VäxtskAnst. 16 (nr 172): 323-425.

REIS, E.R. \& WONSCHE, W.A. 1984. Sporulation of Cochliobolus sativus on residues of winter crops and its relationship to increase of inoculum density in soil. Pl. Dis. 68: 411-412.

Richardson, L.T. 1972. Effectiveness of systemic fungicides seed dressing as protectant of barley seedlings against Cochliobolus sativus. Can. J. Pl. Sci. 52: 949-953.

TEMPE, J. de 1964. Helminthosporium spp. in seeds of wheat, barley, oats and rye. Proc. Int. Seed Test. Assoc. 29: 117-140.

Whittle, A.M. 1977. Cochliobolus sativus on barley in Scotland. Pl. Path. 26: 67-74.

-, \& Richardson, M.J. 1978. Yield losses caused by Cochliobolus sativus on Clermont barley. Phytopath. Z. 91: 238-256.

Ms received January 18, 1985 


\title{
SELOSTUS
}

\section{Bipolaris sorokiniana-sienen merkitys ohran siemenlevintäisenä taudinaiheuttajana Suomessa}

\author{
Aarne Kurppa
}

Helsingin yliopiston kasvipatologian laitos, 00710 HELSINKI 71*

Ohran tyvi- ja lehtilaikkua aiheuttavan Bipolaris sorokiniana-sienen (syn. Helminthosporium sativum, koteloaste Cochliobolus sativus) merkitystä ohran siemenlevintaaisenả taudinaiheuttajana sekä sienen torjuntaa selvitettiin vuosina 1973-1979 Helsingin yliopiston kasvipatologian laitoksella järjestetyissă tutkimuksissa.

Koesiemenenă kăytettiin kenttăkokeella tuotettuja eri asteisesti (19-92 \%) infektoituneita, mutta muilta ominaisuuksiltaan vastaavia siemeneriä ja Valtion Siementarkastuslaitokselta tutkimuksiin valittuja siemeneriä. Erien sienitartunta tutkittiin mikroskooppisesti 7 vrk petrimaljoissa idätetyistă siemenistä. Orastuvuus mäăritettiin virallisen menetelmån mukaisesti. Peittausaineiksi sienen torjuntaan valittiin Ceresankuivapeittausjauhe (organoelohopea), Benlate (benomyyli) ja Kemira Oy:n koe-erä imazalil-valmistetta. Tutkimukseen sisältyneet astiakokeet tehtiin Viikissă ja kenttăkokeet Viikissä sekä Inarissa Muddusniemen tutkimusasemalla.

Orastuvuus astia- ja kenttăkokeissa laskettiin ohran 3-4-lehtiasteella. Kenttäkokeista otettiin laskennan yhteydessä myös orasnăytteet ( 25 orasta/ruutu). Toiset nảytteet koeruuduista otettiin hieman ennen maitotuleentumisastetta. Näytteiden avulla pyrittiin varmistamaan B. sorokiniana-sienen osuus oireiden esiintymiseen sekă seuraamaan taudin kehittymistă. Kasvustot korjattiin heti niiden tuleennuttua. Jyväsadot kuivattiin vălittőmăsti, punnittiin ja niistă tehtiin sienimaaăritykset.

Kylvősiemenen sienitartunta alensi ohran ităvyyttă ja orastuvuutta; peittaamattomien koejäsenten orastuvuus aleni astiakokeissa keskimäärin $14 \%$ ja kenttäkokeissa $18 \%$. Itävyyden ja vielă selvemmin orastuvuuden aleneminen riippuivat enemmän jyvien sisäosien sienitartunnasta kuin jyvien määritetystä sienitartunnasta. Sieni esiintyi yleisemmin itămăttőmissả kuin ităneissä jyvissă. Kylvősiemenen peittaaminen organoelohopeavalmis- teella puhdisti pelkästäăn pinnallisen sienitartunnan saaneet siemenet, mutta ei tăysin torjunut sientă sisăosiltaan infektoituneista jyvistă, joiden itảessả kehittyi sairaita oraita. Systeeminen imazalil antoi paremman torjuntatuloksen kuin elohopea, mutta orastuvuus jäi silti alhaisemmaksi.

Sieni aiheutti useimmissa kokeissa merkitseviă satotappioita sekä alensi kenttäkokeissa lisäksi sadon arvoa kylvősiemenenă, mikăli săảolot olivat suotuisat sienen sekundäärilevinnaalle. Satotappiot astiakokeissa olivat $7.2-38.5 \%$ ja kenttăkokeissa $5-11 \%$, keskimăărin $6.3 \%$. Lajike-erot jăivăt văhăisiksi, todennăkőisenă syynä kaikkien lajikkeiden kylvősiemenen yhtălăinen, voimakas sienitartunta. Peittaaminen lisåsi satoja jonkin verran, muttei tilastollisesti merkitsevästi. Peittausaineista organoelohopea kohotti satoa enemmän kuin imazalil, vaikkei pystynytkäăn torjumaan tautia tăysin. Benomyyli todettiin peittausaineena tăysin tehottomaksi sienen torjunnassa.

Kylvösiemenen sienitartunta johti voimakkaan lehtilaikkutaudin puhkeamiseen kasvustossa tähkälletulon jălkeen kenttăkokeissa Muddusniemen tutkimusasemalla Inarissa, missă sientă ei luontaisena esiinny. Epidemia johti myös jyvăsadon sienitartuntaan. Sieni săilyi maassa satojätteissä kahden talvikauden yli ja kykeni infektoimaan maalevintäisesti ohran oraita.

Siemenlevintă on maassamme todennăköisesti $\boldsymbol{B}$. sorokiniana-sienen tärkein săilymis- ja leviämismuoto. Sienen vahingollisuus ja leviämisvoimakkuus riippuvat kuitenkin paljolti kasvukauden săästä. Kuivana kasvukautena siemenlevintă johtaa pelkästään tyvitautiin, kosteana lisăksi lehtilaikkutautiin ja jyväsadon sienitartuntaan.

\footnotetext{
* Nykyinen osoite: Kasvitautiosasto, MTTK, 31600 Jokioinen
} 